\title{
Intravesical BCG: Possible Protective Impact Against COVID-19 in NMIBC Patients
}

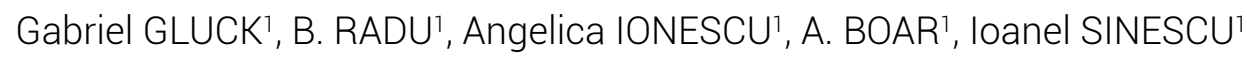

\begin{abstract}
Purpose: To determine the incidence of COVID 19 in a series of registered patients with non-muscle invasive bladder cancer, treated by TUR-BT and intravesical BCG. Patients and method: We analysed 127 patients with nonmuscle invasive bladder cancer, in the medium/high risk group, registered between 2001-2020. The patients and families have been contacted by phone. In this interval, 32 patients deceased (cardiovascular pathologies, non-urologic neoplasia, tumour progression), 95 patients are still alive, 24 women and 71 men. The average age was 61.7 (16-86), the majority being over 50, included in the high-risk group for COVID-19. The patients were resected endoscopically and received a cytostatic instillation within the first 6 hours. Reresection of the tumour bed was practiced in pT1 patients. The adjuvant treatment with BCG was used in the induction form at each relapse and maintenance (22 patients), respectively. Until 2005, we used the local strain (Cantacuzino Clinical Institute), after that, the strain from Bulgaria (Calgevax) and Medac (Germany). Results: 95 patients are still alive. Tumour relapses were registered in 34 patients. 3 patients registered tumour progression, resolved through radical cystectomy (2) and irradiation. In 3 cases, upper tract urothelial tumours were registered (nephroureterectomy with perimeatic cystectomy). 63 patients underwent induction treatment, while 22 underwent maintenance treatment. Complications: Intolerance to BCG in 4 patients, BCG cystitis in 5 patients, arthritis in 1 patient, septic status in 2 patients.

In the analysed batch of patients, no COVID-19 cases have been registered. Conclusions: It appears that the intravesical administration of BCG represents an immunologic booster (confirmable through PPD), resulting in a reduction of the COVID-19 infection incidence.
\end{abstract}

Keywords: COVID-19, bladder cancer, BCG.

\section{Rezumat}

Scop: Stabilirea incidenței COVID -19 la pacienții care sunt în evidența clinicii cu cancer non-invaziv de vezică urinară, tratați prin TURV și BCG intravezical. Pacienți și metodă: Am analizat 127 de pacienți cu tumori non-invazive ale vezicii urinare, în grupa de risc mediu/ mare, luați în evidență între 2001-2020.Pacienții sau familiile au fost contactate telefonic. În acest interval au decedat 32 de pacienți (patologie cardiovasculară, neoplazii non-urologie, progresie tumorală), 95 de pacienți sunt în viață: 24 de femei și 71 de bărbați. Vârsta medie a fost de 61,7 (16-86) ani, majoritatea cu vârsta peste 50 de ani în grupa de risc mare pentru COVID-19.Pacienții au fost rezecați endoscopic și au primit o instilație cu citostatic în primele $6 \mathrm{~h}$. La cei în pT1, s-a practicat rerezecția patului tumoral. Tratamentul adjuvant cu BCG s-a folosit în forma de inducție la fiecare recidivă, respectiv întreținere (22 de pacienți).Până în 2005 am utilizat tulpina autohtonă (IC Cantacuzino), apoi cea din Bulgaria (Calgevax) espectiv Medac (Germania). Rezultate: 95 de pacienți sunt în viață. Recurențe tumorale s-au înregistrat la 34 de pacienți. 3 pacienți au avut progresie tumorală, soluționată prin cistectomie radical (2) respectiv prin iradiere. În 3 cazuri au dezvoltat

${ }^{1}$ Clinic of Urology and Renal Transplantation, Fundeni Hospital, Bucharest, Romania

\section{Corresponding author.}

Gabriel GLUCK, Clinic of Urology and Renal Transplantation,

Fundeni Hospital, Bucharest, Romania.

E-mail: gabrielgluck@yahoo.com 
tumori de uroteliu înalt (nefroureterectomie cu cistectomie perimeatică). Tratament de inducție au făcut 63 de pacienți, tratament de întreținere 22. Complicațiile survenite: intoleranță la BCG 4 pacienți, cistită BCG 5 pacienți,artrită 1 pacient, stare septică 2 pacienți. În lotul de pacienți analizat nu au fost cazuri de COVID-19. Concluzii: Se pare că și administrarea intra vezicală a BCG constituie un rapel imunologic (confirmabil prin PPD), rezultând o reducere a incidenței COVID-19.

Cuvinte cheie: COVID-19, cancer de vezică, BCG.

\author{
Abbreviations \\ BCG - Bacillus Calmette-Guérin \\ COVID-19 - Corona Virus Sars 2 \\ NMIBC - Non muscle invasive bladder cancer \\ PPD - Purified Proteine Derivative \\ TB - Tuberculosis
}

Bacillus Calmette-Guérin (BCG) has been used for almost a century (since 1921) to prevent the tuberculosis infection. Countries with a national BCG vaccination program for the entire population appear to have a reduced incidence and death rate due to COVID-19. This might be explained by the known benefits of the immunity acquired through BCG vaccination. In countries were the BCG vaccination program has been paused (Italy, France, The Netherlands) the morbidity due to COVID-19 is clearly different from other countries, where the vaccination is commonly practiced (countries from the Eastern Europe).

COVID-19 incidence was $0,8 /$ millions inhabitants in countries with BCG vaccination programs and 34.8/ millions inhabitants in countries without vaccination programs. Also, the mortality amounted to 0.08 in countries with $B C G$ vaccination and 34,8 in countries without vaccination program $^{1,2,3,4}$.

In the absence of a specific vaccination against $\mathrm{CO}$ VID-19, the BCG vaccination based on population may play a role in reducing the impact of such disease ${ }^{5}$.

The BCG vaccination decreases the rates of infection with pneumonia, staphylococcus aureus and plays an important role in the protection against viruses, such as influenza, yellow fever and herpes ${ }^{6}$.

\section{PATIENTS AND METHOD}

Patients and methods. We analysed 127 patients with non-muscle invasive bladder cancer, in the medium/high risk group, registered between 2001-2000.
The patients or families have been contacted by phone. In this interval, 32 patients deceased (cardiovascular pathologies, non-urologic neoplasia, tumour progression), 95 patients are still alive, 24 women and 71 men. The average age was 61.7 (16-86), the majority being over 50 , included in the high-risk group for COVID-19. The patients were resected endoscopically and received a cytostatic instillation within the first 6 hours. Reresection of the tumour bed was practiced in pT1 patients. The adjuvant treatment with BCG was used in the induction form at every relapse and maintenance (22 patients), respectively. Until 2005, we used the local strain (Cantacuzino Clinical Institute), after that, the strain from Bulgaria (Calgevaz) and Medac (Germany).

\section{RESULTS}

95 patients are still alive; 16 patients were $\mathrm{pTa}$, but high risk, 75 patients were $\mathrm{pT} 1,4$ patients were $\mathrm{pT} 2$. The tumour relapses were registered in 34 patients. 3 patients registered tumour progression, requiring radical cystectomy (2) and irradiation, respectively. In 3 cases, upper tract urothelial tumours were registered (nephroureterecomy with perimeatic cystectomy). 63 patients underwent induction treatment, while 22 underwent maintenance treatment (12-36 months).

Complications: intolerance to BCG in 4 patients, BCG cystitis in 5 patients, arthritis in 1 patient, sepsis in 2 patients.

In the analysed batch of patients, no COVID-19 cases have been registered.

\section{DISCUSSIONS}

In adults, BCG vaccination is unable to offer complete protection against pulmonary tuberculosis, with an efficiency range between 0 and $80 \%^{7-9}$, which ex- 
plains why TB is one of the major causes of mortality worldwide. Evidence suggests that the $\mathrm{BCG}$ vaccine may offer a long-term protection until $15-20$ years $^{10,11}$. Consequently, it was assumed that the protective effect of the BCG vaccine is likely to last for 15 years, without reducing the efficacy of the vaccine within this period $^{12,13,14,15}$.

BCG vaccination during childhood and teenage induces the immunologic memory to tuberculosis antigens, which are still present and measurable in the majority of vaccinated persons ${ }^{16}$. BCG protection may decrease in time since vaccination. A study from Norway, conducted over 41 years on patients between 12-50 years old, shows different protection numbers: an average of $49 \%$ efficiency of the BCG vaccination ${ }^{18}$.

In case of previously vaccinated persons, the recent studies showed that the re-vaccination is safe, well tolerated and is not associated with an increased frequency or severity of the local or systemic reactions, as compared to the primary BCG vaccination ${ }^{11}$. On the other hand, the revaccination might extend the protection duration against tuberculosis infection, offered by BCG, assertion confirmed through the tuberculin test.

Studies showed that anti TB antibodies titre (gamma interferon range) objectified through the tuberculin test (PPD) and with role in the protection against tuberculosis infection, evolves extremely different.

In children, it is maintained at $75 \%$, in adults at $50 \%$ and may oscillate between 0 and $80 \%$.

In countries at risk, boosters are carried out1-2 in teenagers and at 18 years old (first vaccination is administrated during suckling).

Three new clinical trials started recruiting for testing the hypothesis according to which the BCG vaccination may protect against COVID-19 in healthcare workers. Clinical trials in Australia („BRAVE”; PI Curtis), USA („BADAS”; PI: Kamat, Dinardo) and the Netherlands (PI: Netea) intend to randomise cumulati-

\section{References}

1. European Centre for Disease Prevention and Control. Distribution of COVID-19 cases. www.ecdc.europa.eu/en/geographicaldistribution-2019-ncov-cases.

2. Worldometer. Countries in the world by population (2020). www. worldometers.info/world-population/population-by-country.

3. Zwerling A, Behr MA, Verma A, Brewer TF, Menzies D, Pai M. The BCG World Atlas: a database of global BCG vaccination policies and practices. PLoS Med 2011;8:e1001012.

4. Hegarty PK, et al. COVID-19 and Bacillus Calmette-Guérin: What is the Link? Eur Urol Oncol (2020), https://doi.org/10.1016/j. euo.2020.04.001 vely 6.000 workers in the health field for BCG vaccination against a placebo agent ${ }^{19,20,21,22}$. Another casecontrol observational study in Egypt started to recruit COVID-19 positive patients to compare the severity of the disease in patients tested positive for BCG with negative ones ${ }^{12}$.

Regarding patients who benefit from intravesical BCG therapy for bladder cancer, the potential effects of this treatment on COVID-19 are not clear. The mechanism of action following the vaccination and intravesical administration differs significantly ${ }^{13,14}$. BCG, apart from the local effect, appears to have a systemic effect with impact on the acquired immunity. Our hypothesis is that the intravesical instillations represent a clear booster inducing the control of the cytokine storm syndrome, involved in COVID-19 morbidity.

A BCG phial used for bladder cancer is 500 times higher than the dose necessary for vaccination, another quantitative element justifying the systemic answer. Approximatively $40 \%$ of patients with intravesical BCG induction become positive to the PPD test. There are studies showing that for this reason, patients became immune to tuberculosis, due to BCG inductions. Webinar Ashim Kamat ${ }^{22}$.

\section{CONCLUSIONS}

It appears that the intravesical administration of BCG represents an immunologic booster (confirmable through PPD), resulting in a reduction of the COVID- 19 infection incidence.

Compliance with ethics requirements: The authors declare no conflict of interest regarding this article. The authors declare that all the procedures and experiments of this study respect the ethical standards in the Helsinki Declaration of 1975, as revised in 2008(5), as well as the national law. Informed consent was obtained from all the patients included in the study.

5. M. Gursel, I. Gursel, Is Global BCG Vaccination Coverage Relevant To The Progression Of SARS-CoV-2 Pandemic?, Medical Hypotheses (2020), doi: https://doi.org/10.1016/j.mehy.2020. 109707

6. Clin Microbiol Infect. 2019 Dec;25(12):1473-1478. doi: 10.1016 /j.cmi.2019.04.020. Epub 2019 May Non-specific effects of BCG vaccine on viral infections. Moorlag SJCFM, Arts RJW, van Crevel R(2), Netea MG.

7. Colditz GA, Brewer TF, Berkey CS, Wilson ME, Burdick E, Fineberg $\mathrm{HV}$, et al. . Efficacy of BCG Vaccine in the Prevention of Tuberculosis: Meta-analysis of the Published Literature. J Am 
Gabriel GLUCK et al.

Med Assoc. (1994) 271:698-702. 10.1001/jama.271.9.698 [PubMed] [CrossRef] [Google Scholar]

8. Fine PEM. Variation in protection by BCG: implications of and for heterologous immunity. Lancet. (1995) 346:1339-45. 10.1016/ S0140-6736(95)92348-9 [PubMed] [CrossRef] [Google Scholar]

9. Brewer TF. Preventing tuberculosis with Bacillus CalmetteGuérin vaccine: a meta-analysis of the literature. Clin Infect Dis. (2000) 31:S64-7. 10.1086/314072 [PubMed] [CrossRef] [Google Scholar]

10. Abubakar I, Pimpin L, Ariti C, Beynon R, Mangtani P, Sterne JA, et al. Systematic review and meta-analysis of the current evidence on the duration of protection by bacillus Calmette-Guerin vaccination against tuberculosis. Health Technol Assess. 2013;17(37):1-372, v-vi.

11. Nguipdop-Djomo P, Heldal E, Rodrigues LC, Abubakar I, Mangtani P. Duration of BCG protection against tuberculosis and change in effectiveness with time since vaccination in Norway: a retrospective population-based cohort study. The Lancet Infectious Diseases. 2016;16(2):219-26.

12. Outcome of COVID-19 cases based on tuberculin test: can previous BCG alter the prognosis? (2020). https://clinicaltrials.gov/ ct2/show/NCT04347876

13. Redelman-Sidi G, Glickman MS, Bochner BH. The mechanism of action of BCG therapy for bladder cancer - a current perspective. Nat. Rev. Urol. 11(3), 153-162 (2014).

14. Steigler $P$, Verrall AJ, Kirman JR. Beyond memory $T$ cells: mechanisms of protective immunity to tuberculosis infection. Immunol. Cell Biol. 97(7), 647-655 (2019).
15. Buffen $\mathrm{K}$, Oosting M, Quintin J et al. Autophagy controls BCGinduced trained immunity and the response to intravesical BCG therapy for bladder cancer. PLoS Pathog. 10(10), e1004485 (2014).

16. Persistence of the immune response induced by BCG vaccination Rosemary E Weir, Patricia Gorak-Stolinska*, Sian Floyd, Maeve K Lalor, Sally Stenson, Keith Branson, Rose Blitz, Anne Ben-Smith, Paul EM Fine and Hazel M Dockrell

17. BMC Infectious Diseases 2008, 8:9 http://www.biomedcentral. com/1471-2334/8/9 Sterne JA, Rodrigues LC, Guedes IN. Does the efficacy of BCG decline with time since vaccination?. Int J Tuberc Lung Dis. 1998;2(3):200-207

18. Nguipdop-Djomo P, Heldal E, Rodrigues LC, Abubakar I, Mangtani P. Duration of BCG protection against tuberculosis and change in effectiveness with time since vaccination in Norway: a retrospective population-based cohort study. Lancet Infect Dis. 2016;16(2):219-226. doi:10.1016/S1473-

19. BCG vaccination to protect healthcare workers against COVID-19 (BRACE) (2020). https://clinicaltrials.gov/ct2/show/record/NCT04327206

20. Reducing healthcare workers absenteeism in Covid-19 pandemic through BCG vaccine (BCG-CORONA) (2020). https://clinicaltrials.gov/ct2/show/NCT04328441

21. BCG vaccine for healthcare workers as defense against SARSCOV2 (2020). https://clinicaltrials.gov/ct2/show/NCT04348370

22. Bladder Cancer Advocacy Network. COVID-19 (novel coronavirus) and bladder cancer: what patients and families need to know. 